\title{
Rose-ringed parakeet (Psittacula krameri) and starling (Sturnus vulgaris) syntopics in a Mediterranean urban park: evidence for competition in nest-site selection?
}

\author{
Giuseppe Dodaro ${ }^{1}$ \& Corrado Battisti ${ }^{2, *}$
}

\begin{abstract}
1 Ambiente Italia s.r.l., via Vicenza 5a, 00185 Rome (Italy); e-mail:giuseppe.dodaro@ambienteitalia.it
2 "Torre Flavia” LTER (Long Term Environmental Research) Station, Servizio Ambiente, Provincia di Roma, via Tiburtina, 691, 00159 Rome (Italy); e-mail: c.battisti@provincia.roma.it

* Corresponding author: c.battisti@provincia.roma.it
\end{abstract}

\begin{abstract}
Introduced species may compete with indigenous ones, e.g. for space resources, but evidence for syntopic cavity-nester birds is limited, at least for Mediterranean urban parks. In this work we report data on nest-site habitat use, availability and selection in two species: the introduced rose-ringed parakeet (Psittacula krameri) and the autochthonous starling (Sturnus vulgaris) nesting in ornamental tree (Cedrus libanotica) patches occurring in an historical urban park (Rome, central Italy). In particular, in our study we hypothesize that parakeets negatively affect starling nest-site selection. On 55 trees, we detected 73 available holes for nesting (38.4\% of which hosted nests: 9 of rose-ringed parakeet, 16 of starling, 3 of house sparrow). Birds utilized for nesting only a limited number $(<20 \%)$ of the ornamental trees (all larger than $80 \mathrm{~cm}$ in diameter). Compared to the total number of available trees, nesting trees had a significantly larger diameter at breast height. We observed a shift in the frequency distribution of nest hole height classes between starlings and parakeets suggesting competition for nesting sites between these two species. Starlings located their nests significantly lower than did rose-ringed parakeets, resulting in a higher specialization for starlings (as measured by the Feinsinger index) than for rose-ringed parakeets. The analysis of co-occurrence highlights a spatial segregation in nest holes. We argue that these differences in preferred nest height are indicative of parakeet dominance over starlings in cavity selection for nesting.
\end{abstract}

KEY WORDS: height habitat selection, niche overlap, competition, introduced species, central Italy.

\section{INTRODUCTION}

Introduced species may compete for resources with indigenous ones (e.g. nest-holes, food for juvenile recruitment; DAVIS, 2003). Particularly in communities where strong interspecific competition between native species is lacking, exotic and native species often exhibit intense competition resulting in the decline of native populations (EDELMAN et al., 2009). However, evidence of similarly negative competition effects in syntopic birds is limited, at least for some species (BAUER \& WOOG, 2008, 2011). This situation is even more striking in a group of vertebrates such as the birds, where data quality with respect to occurrence, numbers and population trends is usually very high
(EBENHARD, 1988, BLACKBURN et al., 2009; KeSTENHOLZ et al., 2005).

Urban parks embedded in anthropized landscapes host peculiar ecosystems, biological communities and species (REBELE, 1994; ClergeaU, 2006). In urban areas wooded patches are often composed of ornamental vegetation characterized by a high density of large, mature trees that have not been subjected to intensive coppice management. As a consequence there is often high availability of cavities, invertebrates and plant food (FALK, 1976; DORNEY et al., 1984; MCKINNEY, 2002), and urban parks may therefore host a specific guild of specialized species, such as the cavity nesting birds (BEISSINGER \& OsBORNE, 1982, BlAir, 2001). 
Cavity nesting birds, also named "hole-nesting birds", represent a guild of species (such as woodpeckers, nuthatches, tits, treecreepers, starlings and sparrows) highly dependent on old trees or dead wood for nesting, and secondarily, for roosting and feeding. This guild can be divided into (i) excavators (e.g., woodpeckers), species that excavate cavities secondarily used by insects, reptiles, birds and mammals, and (ii) non-excavators, a large number of species that use natural or previously excavated tree holes for nesting (MARTIN \& LI, 1992; MARTIN \& EADIE, 1999; BlanC \& WALTERS, 2008). The occurrence, abundance and richness of cavitynesting birds largely depend on the availability of suitable nesting cavities and food resources linked to mature trees (CRAMP \& PERRINS, 1993).

Cavity-nesting bird guilds include rare and specialized species but also generalist and synanthropic ones (both urban adapters and exploiters). The latter are linked to humantransformed habitats and often exhibit more flexibility in nest site choice (e.g. nesting also in buildings; BLAIR, 2001). Synanthropic species may be secondarily adapted to humantransformed ecosystems (termed 'adapters') or actively select these environments (termed 'exploiters'; see BLAIR, 2001). Moreover, many synanthropic species are not native (e.g. some species of parakeets, order Psittaciformes).

In this study, we focused on two synanthropic species that are commonly found in forest patches of South-European urban parks. Our first study species, the starling (Sturnus vulgaris) (Linnaeus, 1758), is a species that, over the last decades, has become more and more abundant in anthropized landscapes across the Southern Mediterranean region (BIRDLIFE INTERNATIONAL, 2004). This contrasts strongly with its status in Northern Europe, where it is declining and disappearing from urban areas (ROBINSON et al., 2005; Mennechez \& Clergeau, 2006). Secondly, we assessed the rose-ringed parakeet (Psittacula krameri) (Scopoli, 1769), an introduced species (JUNIPER and PARR, 1998) that has established self-sustaining (i. e. naturalized) populations in many European cities (CASSEY et al., 2004; CZAJKA et al., 2011, NeWSON et al., 2011). Previous studies have suggested that because of a strong overlap in preferred nesting cavities, starlings and rose-ringed parakeets are likely to compete for tree cavities in the areas where they co-occur, although empirical evidence for competition between these species is currently lacking (STRUBBE \& MATTHYSEN, 2007, StRubBe \& MATTHYSEN, 2009a, 2010, CZAJKA et al., 2011, NEWSON et al., 2011). However, these studies have been carried out in Northern and Central Europe, and information on habitat and nesting preferences of these species in the Mediterranean area remains rare.

In this work, we focused on ecological traits related to the selection of nest holes of the two locally most abundant species: rose-ringed parakeet, an introduced species, and starling. We tested whether there are differences in the height of the cavities that are selected for breeding by both species. In particular, since we observed localized syntopy (i.e. an occurrence of individuals in the same wood patches) between these two species, we tested the hypothesis that locally, rose-ringed parakeets may negatively affect starling nest-site selection.

\section{MATERIALS AND METHODS}

\section{Study area}

The study was carried out inside the Villa Doria Pamphili (Rome, central Italy), a large urban park (about 120 hectares, about $50 \mathrm{~m}$ a.s.1.) designed as a Site of Nature Conservation Interest (SNCI) ('Habitat' Directive 92/43/EEC; $\left.41^{\circ} 53^{\prime} \mathrm{N}, 12^{\circ} 27^{\prime} \mathrm{E}\right)$. This historical urban park, embedded in a continuous urbanized matrix, was created in the $17^{\text {th }}$ century and represents a heterogeneous patchy landscape with wood fragments where oaks are dominant tree species (Quercus ilex, Q. pubescens, Q. petrae). Wooded patches with ornamental tree species (Cedrus libanotica, Cupressus sp. and others), open areas, 
and artificial lakes also occur (BATTISTI, 1986; Celesti-Grapow, 1995). Inside the study area, we focused the sampling protocol on a small wooded patch composed of ornamental trees (size area: 0.5 ha; 57 trees: 55 Cedrus libanotica, 1 Cupressus sp., 1 Platanus orientalis).

\section{Field Methodology}

Inside the forest patch, we analysed only data of Cedrus libanotica trees $(\mathrm{n}=55)$. For each tree, we measured the diameter at breast height $(\mathrm{DBH}$, in $\mathrm{cm})$ and the tree height $(\mathrm{TH})$ in size classes $(0-2 \mathrm{~m},>2-4,>4-6,>6-8,>8-10,>10-12$, $>12-14,>14-16)$ obtaining a mean value of these two parameters (MEAN DBH and MEAN TH). Each tree was surveyed for cavities potentially suitable for cavity-nesting birds (hole nests; see BIBBY et al., 2000). Each tree hole discovered was assigned to a height class (see above), and during the breeding season, we determined whether a cavity-nesting bird occupied it or not. From March to June 2012, we carried out six visits to the study area in the first hours of the morning (about 07.00 a.m.), when these species are more easily detectable near the hole nests, to the late morning (about 11.00 a.m.), when foraging activities are more intense (e.g. for juvenile recruitment) so allowing the detection of hole nests (total research effort: about 24 hours).

\section{Data Analysis}

First, to test whether rose-ringed parakeet and starling nest site choice was neutral with respect to the height at which cavities were located or not, we calculated the Feinsinger index (FEINSINGER et al., 1981). We first calculated the frequency of available occupied holes for each height class, allowing us to obtain the Feinsinger index through the following formula (FEINSINGER et al., 1981):

$$
\text { PS }=1-0,5 \Sigma\left|p_{i}-q_{i}\right|
$$

In this index, $\mathrm{p}_{\mathrm{i}}$ is the proportion of the utilized resource (i.e., the frequency of nest holes in each tree height class) and $\mathrm{q}_{\mathrm{i}}$ the proportion of the available resource (i.e., the frequency of available holes in each tree height class). The index varies from 0 (extreme specialist for that specific resource) to 1 (extreme generalist).

Second, in order to assess the degree to which rose-ringed parakeet and starling nest site choice overlaps, we applied a niche overlap index. Nesting site niche overlap was obtained through the following formula (KREBS 1989):

$$
\text { Oi }=\Sigma\left(p_{j 1} p_{j 2} / a_{j}\right) \text {, }
$$

where $p_{j 1}$ and $p_{j 2}$ are the relative frequencies, respectively, of the species 1 and 2 recorded among the habitat type $\mathrm{j}$, and $\mathrm{a}_{\mathrm{j}}$ is the relative frequency of the available habitat type $\mathrm{j}$. The index varies from 0 (absence of overlapping) to 1 (total overlap).

To assess whether rose-ringed parakeets and starlings significantly differ in nest site choice, we compared the frequency distribution of nesting cavity heights for the two species using a Kolmogorov-Smirnov test. To test whether parakeets and starlings prefer trees with different average values in $\mathrm{DBH}$, we performed the non parametric U Mann-Whitney test for unpaired data (DYTHAM, 2011).

We performed all statistical non parametric analyses using SPSS version 13.0 (SPSS Inc., 2003). We assumed an alpha level of $5 \%$ as level of significance.

Moreover, we performed a null model analysis of species co-occurrence pattern in order to test whether the two study birds avoided colonizing a tree already occupied by the other species (GOTELLI, 2000). As the co-occurrence measure, we used the STONE and RoBERTs' (1990) $\mathrm{C}$-score. The $\mathrm{C}$-score measures the average number of "checkerboard units" between all possible pairs of species. The number of checkerboard units $(\mathrm{CU})$ for each species pair is calculated as: $C U=\left(r_{i}-S\right)\left(r_{j}-S\right)$, where is $\mathrm{S}$ is the number of shared sites (sites containing both species) and $r_{i}$ and $r_{j}$ are the row totals for species $\mathrm{i}$ and $\mathrm{j}$. The $\mathrm{C}$-score is the average of 


\section{TABLE 1}

Mean diameter (and standard deviation, s.d.) at breast height (MEAN DBH, in $\mathrm{cm}$ ) and mean tree height (MEAN $\mathrm{TH}$; and standard deviation, s.d.) both for all Cedrus libanotica trees and for trees occupied by the two cavity nesters studied: rose-ringed parakeet (Psittacula krameri) and starling (Sturnus vulgaris).

\begin{tabular}{|l|c|c|c|}
\hline Categories & N & MEAN DBH (s.d.) & MEAN TH (s.d.) \\
\hline All trees & 55 & $65.05(25.06)$ & $11.87(2.90)$ \\
With available holes & 10 & $97.79(11.89)$ & $14.50(1.51)$ \\
With nest holes & 9 & $94.78(8.34)$ & $14.33(1.73)$ \\
With rose-ringed parakeet holes & 4 & $94.5(7.93)$ & $14.50(1.00)$ \\
With starling holes & 7 & $94.36(8.14)$ & $14.43(1.90)$ \\
\hline
\end{tabular}

all possible checkerboard pairs, calculated for species that occur at least once in the matrix. The C-Score measures the tendency for species to not occur together. The larger the $\mathrm{C}$-score, the less the average co-occurrence among species pairs. If a community was structured by competition, we would expect the $\mathrm{C}$-score to be large relative to a randomly assembled community (GOTELLI 2000; GOTELLI \& ENTSIMNGER 2001). As randomization algorithm we used (i) "fixed sum" as row constraint and (ii) "equiprobable" for column constraint, that is: (i) the observed row totals are maintained in the simulation (the number of occurrences of each species in the null communities is the same as in the original data set), and (ii) each column (site) is equally likely to be represented (we supposed that all trees are equivalent to one another, that is from the species perspective, all the trees with holes are equally likely to be successfully colonized). With this randomization algorithm, in the simulation, the occurrences for each species (row sums) are distributed randomly among the different columns (GOTELLI \& ENTSIMNGER 2001). For each occurrence, a column is chosen randomly and equiprobably, although if a cell already has a 1 placed in it, another column is randomly chosen until an empty site is found. This procedure is repeated until all of the occurrences of each species are randomly distributed among the columns. The analyses of co-occurrence were performed by using Ecosim software (GOTELLI \& ENTSIMNGER 2001).

\section{RESULTS}

In the wooded patch, the mean diameter at breast height of the Cedrus libanotica trunks was $65.05 \mathrm{~cm}( \pm 25.06)$ and the mean tree height was $11.87 \mathrm{~m}( \pm 2.89)$. Among the trees, 17 $(30.91 \% ; \mathrm{n}=55)$ showed a diameter $>80 \mathrm{~cm}$, $12(21.82 \%)$ hosted available holes for nesting, and $9(16.36 \%)$ hosted holes with nests (all with a diameter $>80 \mathrm{~cm})$.

In total, we detected 73 available holes for nesting. Among them 28 (38.4 \%) hosted bird nests: 9 of rose-ringed parakeet $(32.1 \%$ of occupied nests); 16 of starling (57.1\%). We also detected 3 hole nests (10.7\%), of house sparrow (Passer domesticus) (Linnaeus, 1758), a synanthropic species, recently declining in density and distribution at the continental scale (SUMMER-SMITH, 2003): these data were not included in the following analyses. Fortyfive holes remained empty. Data on mean tree diameter and mean tree height of available holes and occupied nests for these three species are given in in Tables 1 and 2 .

The mean height of starling nests in tree cavities was significantly lower when compared to mean height of rose-ringed parakeet nests $(Z=-2.159$, $\mathrm{p}<0.05$, Mann-Whitney $U$ test) and lower than the mean of all available holes $(Z=-2.873$, $\mathrm{p}<0.01$, Mann-Whitney U test), while nests of rose-ringed parakeet were not significantly 


\section{TABLE 2}

Number of available and occupied hole nests, their density (D; in nests/ha) in Cedrus libanotica patch and mean nest height (MEAN NEST NH; in m, and standard deviation, s.d.) for the two cavity nesters studied: rose-ringed parakeet (Psittacula krameri) and starling (Sturnus vulgaris). $\left(^{*}\right)$ included three nests of house sparrow (Passer domesticus).

\begin{tabular}{|l|c|c|c|}
\hline & N & D & MEAN NEST NH (s.d.) \\
\hline All available holes & 73 & 146 & $7.82(2.97)$ \\
Rose-ringed parakeet hole nests & 9 & 18 & $8.17(2.83)$ \\
Starling hole nests & 16 & 32 & $5.38(2.80)$ \\
total hole nests (*) & 28 & 56 & $6.66(3.06)$ \\
\hline
\end{tabular}

different when compared to the mean height of all available holes $(\mathrm{Z}=0.175, \mathrm{p}=0.845)$.

Analyzing the frequency distribution of data, we corroborate the previous results. In particular, we observed a shift between the frequency distribution of height classes of nest holes between rose-ringed parakeet and starling (Fig. 1). The frequency distribution of total available holes was not significantly different from the frequency distribution of rose-ringed parakeet $(Z=0.349$, $\mathrm{p}=1$ ), i. e. parakeets used nest sites according to availability, while our results show a trend towards a significant difference between starling nests and total available holes $(\mathrm{Z}=1.278, \mathrm{p}=$ 0.076, Kolmogorov-Smirnov two sample test),

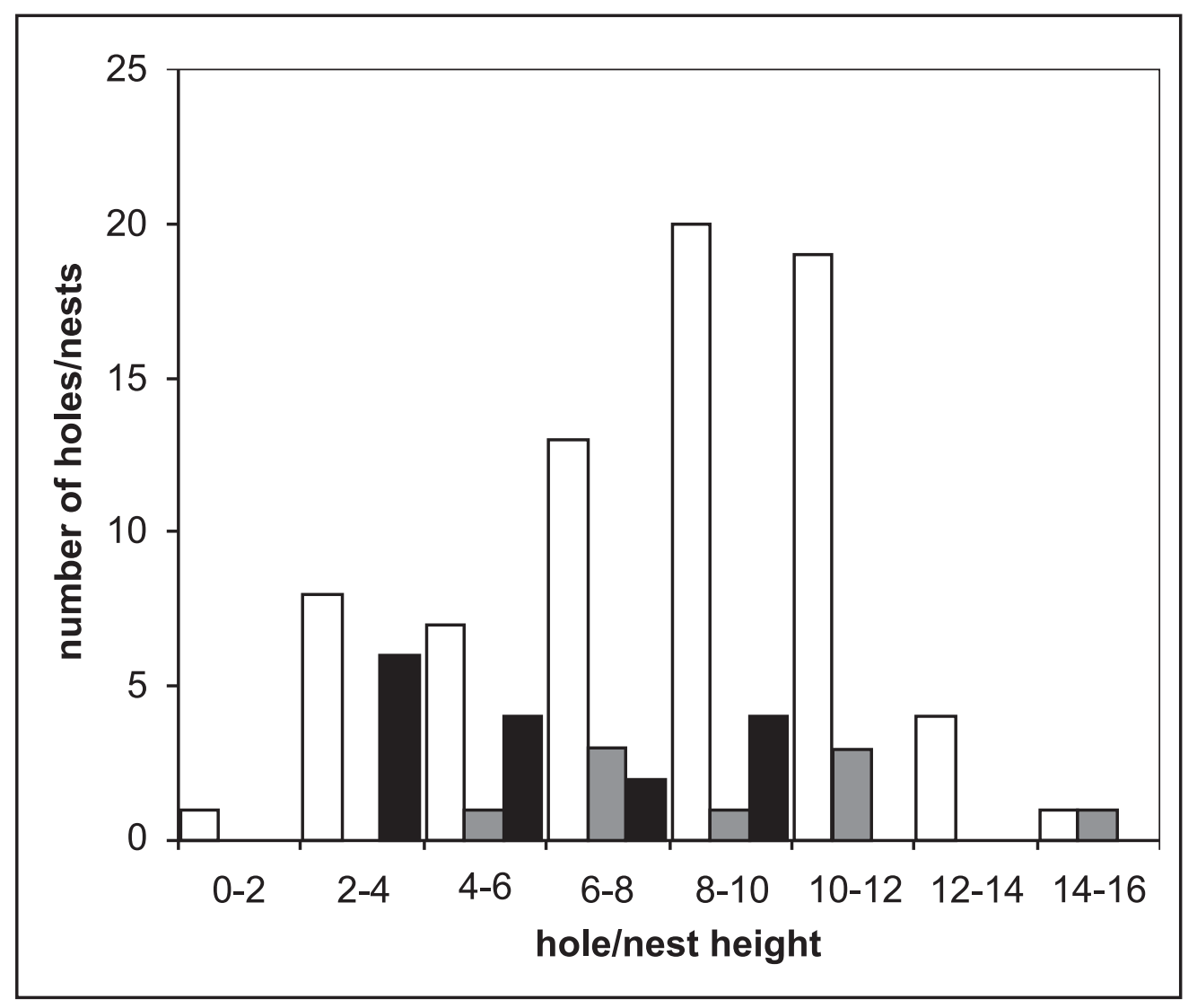

Fig. 1. - Available (in white) and occupied holes (nests) subdivided for categories (grey: rose-ringed parakeet, Psittacula krameri; black: starling, Sturnus vulgaris). 
i.e. starlings showed a preference. In starlings we observed a higher frequency of nest holes at lower height classes whereas the frequency distribution of total available holes was lower, $\mathrm{i}$. e. nesting cavities of starlings were significantly lower than parakeet nests (Fig. 1).

The Feinsinger index showed a higher value in rose-ringed parakeet $(0.659)$ when compared to starling (0.581), indicating that parakeets are more generalists than starlings in regard to nest site choice. Niche overlap index between these two species was 0.625 .

The analysis of co-occurrence performed on the distribution of the 19 trees colonized by at least one species and with at least one empty hole available to be colonized, showed that the two species were spatially segregated (observed $\mathrm{C}$-score index $=60.00$; mean of simulated indices $=20.25$; Variance of simulated indices $=102.25$; $\left.\mathrm{p}_{\text {(obs } \geq \exp )}=0.002\right)$.

\section{DISCUSSION}

In this study, we assessed nest site choice of two synanthropic cavity-nesters, the (native) starling and the (introduced) rose-ringed parakeet. These two species are often considered to be urban exploiters, i.e. belonging to a guild of species commonly found in urban parks and suburban landscapes, and are adapted to edge habitats, human dwellings and small-sized forest patches occurring in urban parks (ADAMS, 1994; BLAIR, 2001).

Parakeets and starlings reached high breeding densities in our study area (18 and 32 nests/ha, respectively), and this is probably due to plentiful availability of large trees (Cedrus libanotic) with many holes (146 tree holes/ha). In this urban park, only ornamental and allochthonous trees showed a mean diameter at breast height larger than $80 \mathrm{~cm}$, since trees belonging to the natural vegetation (mainly oaks, Quercus spp.) rarely have a diameter greater than $50 \mathrm{~cm}$ (BATTISTI, 1986). The occurrence of large trees in historical urban parks has been highlighted as an important feature to allow the breeding of hole-nesting birds (HINSLEY et al., 1995; MIKUSIŇSKI et al., 2001). In our study, the detected synanthropic hole-nesting birds utilized only a limited number of trees $(<20 \%)$, with a significantly larger mean diameter when compared to the total number of available trees. Thus, our results show that ornamental allochthonous tree species can have a high ecological value for urban hole-nesting birds, many of them species of high ecological interest and conservation concern due to their sensitivity to coppice management, forest fragmentation, isolation and degradation (e.g. Cieslak, 1985; Helle, 1985; Opdam et al., 1985; MATTHYSEN et al., 1995; BELLAMY et al., 1996; ZANGHERI et al., 2013).

The starling is one of the most common secondary cavity-nesters in Europe, breeding in central Italy from 1970s (ANGELICI \& PAZIENTI, 1985) and nowadays occurs almost throughout the whole country (CECERE et al., 2005). For this species, a significant correlation between cavity availability and species abundance has been reported (STRUBBE \& MATTHYSEN, 2007). This species is known to compete with other cavity nesters for nest-site (e.g. woodpeckers: INGOLD, 1994). When introduced, starling is also considered an aggressive secondary cavity nester (PELl \& TideMANN, 1997; KoENIG, 2003; MARTIN et al., 2004).

Differing from starlings, the rose-ringed parakeet is an allochthonous species, widely introduced in urban areas in Italy since the 1980s (SPANÒ \& TRUFFI, 1986; MORI et al., 2013; for Rome: ANGELICI, 1984; BRUNELLI et al., 2011). Although some studies on parakeet nesting behaviour and habitat choice have been conducted in Northern Europe (e. g. CZAIJKA et al., 2011), such information is still lacking from Mediterranean areas. In Northern Europe, starlings are considered to be vulnerable to competition with rose-ringed parakeets (STRUBBE \& MATTHYSEN, 2007, 2009a, 2009b, STRUBBE at al., 2010). However, StRUBBE and MATTHYSEN (2007), BRAUN et al. (2009) and CZAIJKA et 
al. (2011) found a niche separation in regard to tree size and tree species between the nests of parakeets and starlings in German and Belgian city parks, suggesting that differing nesting site preferences may reduce competition between these species. Our data, obtained from a single ornamental tree species (Cedrus libanotica), suggest that in our study area, parakeets and starlings may compete for nesting cavities as the starling shows a higher specialization in nest height selection, breeding at lower heights than rose-ringed parakeets. Also, we observed a partial niche overlap in nest choice between these two species, suggesting a moderate interspecific competition. As the height at which cavities are located may be related to predation risk (NILSSON, 1984), our data suggest that parakeet competition may force starlings to breed in lower, and thus less-safe cavities.

Our evidence for possible competition between these two species when occurring in syntopy is further supported by the results of statistical analysis for co-occurrence. It is possible, however, that our data may be affected by a local effect (the detection of competition among bird species is largely affected by the scale of investigation; BENNETT, 1990). Therefore, it is possible that geographical and ecological contexts and circumstances are of great importance to predict whether a certain species may be affected by competition (KoENIG 2003). For example, studying the competition between nutchatch (Sitta europaea) and rose-ringed parakeet, NEWSON et al. (2011) suggested the possibility that competitive exclusion occurred at a minority of sites where availability of nest cavities was limited.

We propose that further research should be carried out because in our study direct competition (e.g. aggressive interactions) between these two species has not yet been observed, nor is it clear whether the pattern in nest site choice found here actually influences the starling's reproductive success (KERPEZ \& SMITH, 1990; PELL \& TidemanN, 1997; Strubbe \& MATthysen, 2007).
Our data also suggest that rose-ringed parakeet may be included in a proposed 'grey list' of nonnative species (ESSL et al., 2008), i.e. a list that includes those introduced species for which there is evidence that native bird populations may be affected by their presence, but for which more research seems necessary to decide whether the increase and spread of this species may warrant further conservation actions (BAUER \& WOOG, 2011).

Finally, the present study could also provide evidence that an exotic ornamental tree such as Cedrus libanotica to some extent favours the success of introduced bird species, because the rose-ringed parakeets do not nest on buildings (contrarily to native starlings and sparrows). This fact suggests suitable future conservation actions to control parakeet populations through the management of this exotic ornamental tree.

\section{ACKNOWLEDGEMENTS}

Two anonymous reviewers have largely improved a first draft of the manuscript. We would acknowledge also Dr. PhD. Leonardo Vignoli (University of Rome III) for your support in statistical analyses.

\section{REFERENCES}

ADAMS LW (1994). Urban wildlife habitats. University of Minnesota press, Minneapolis.

ANGelici FM (1984). Il Parrocchetto dal collare Psittacula krameri (Scopoli) è presente in libertà anche a Roma. Avifauna, 7: 179-180.

ANGelici FM \& PAZIENTI A (1985). Tre nuove colonie di Storno Sturnus vulgaris nella città di Roma. Rivista italiana di Ornitologia, 55: 181182.

Battisti C (1986). Censimento degli uccelli nidificanti in un parco urbano (Villa Doria Pamphili, Roma). Avocetta, Italian Journal of Ornithology, 10: 37-40.

BAUER H-G \& WOOG F (2008). Non-native and naturalized bird species (neozoa) in Germany, 
part I: occurrence, population size and status. Vogelwarte, 46: 157-194.

BAUER G \& WOOG F (2011). On the 'invasiveness' of non-native bird species. Ibis, 153: 204-206.

BENNETT WA (1990). Scale of investigation and the detection of competition : an example from the house sparrow and house finch introductions in North America. The American Naturalist, 135: 725-747.

BLACKBURN TM, LOCKWOOD JL \& CASSEY P (2009). Avian Invasions. The Ecology and Evolution of Exotic Birds. Oxford: Oxford University Press.

Braun M, CZAJKa C \& Wink M (2009). Gibt es eine Brutplatzkonkurrenz zwischen Star und Halsbandsittich? Vogelwarte, 47: 361-362.

BEISSINGER SR \& OSBORNE DR (1982). Effects of urbanization on avian community organization. Condor, 84: 75-83.

Bellamy PE, Hinsley SA \& Newton I (1996). Factors influencing bird species numbers in small woods in south-east England. Journal of Applied Ecology, 33: 249-262.

BibBy CJ, Burgess ND, Hill DA \& Mustoe SH (2000). Bird census techniques. II Ed., Academic Press, Londra, UK.

BIRDLIFE INTERNATIONAL (2004). Birds in Europe: population estimates, trends and conservation status. BirdLife Conservation Series, 12, BirdLife International, Canbridge, UK.

BLAIR RB (2001). Birds and butterflies along urban gradients in two ecoregions of the United States. In: LOCKWOOD JL \& MCKINNEY ML (Eds.), Biotic homogenization. Kluwer, Norwell, MA: 33-56.

BlanC A \& Walters JR (2008). Cavity excavation and enlargement as mechanisms for indirect interactions in an avian community. Ecology, 89: 506-514.

Brunelli M, SARrocco S, Corbi F, Sorace A, BoAno A, De Felici S, Guerrieri G, Meschini A \& RomA S (2011). Nuovo Atlante degli Uccelli Nidificanti nel Lazio. Edizioni ARP (Agenzia Regionale Parchi), Roma.

BUTLER, CJ (2005). Feral parrots in the Continental United States and United Kingdom: past, present, and future. Journal of Avian Medicine and Surgery, 19:142-149.

CAssey P, Blackburn TM, Russel GJ, Jones KE \& LOCKWOOD JL (2004). Influences of the transport and establishment of exotic bird species: an analysis of the parrots (Psittaciformes) of the world. Global Change Biology, 10: 417-426.

Cecere JC, Sorace A \& De Santis E (2005). Distribuzione dello Storno Sturnus vulgaris nella città di Roma. Alula, 12: 85-86.

CELesti Grapow L (1995). Atlante della flora di Roma. La distribuzione delle piante spontanee come indicatore ambientale. Comune di Roma, Argos edizioni, Roma.

CIESLAK M (1985). Influence of forest size and other factors on breeding bird species number. Ekologia Polska, 33: 103-121.

Cignini B \& Zapparoli M (1996). Atlante degli uccelli nidificanti a Roma. F.lli Palombi Editore, Roma.

Clergeau P, Croci S, Jokimäki J, KaisanlahtiJOKIMÄKI M-L \& DINETTI M (2006). Avifauna homogenization by urbanisation: Analysis at different European latitude. Biological Conservation, 127 : 336-344.

CRAMP S \& PERrins CM (1993). The Birds of the Western Palearctic. Vol. VII. Oxford Univ Press, Oxford.

CZAIJKA C, BRAUN MP \& WinK M (2011). Resource use by non-native Ring-Necked Parakeets (Psittacula krameri) and native Starlings (Sturnus vulgaris) in Central Europe. The Open Ornithology Journal, 4: 17-22.

DAVIS MA (2003) Biotic Globalization: Does Competition from Introduced Species Threaten Biodiversity? BioScience, 5: 481-489.

Dorney JR, Guntenspergen GR, Keugh JR \& STERNS F (1984). Composition and structure of an urban woody plant community. Urban Ecology, 8: 69-90.

Dytham C (2011). Choosing and using statistic. A Biologist's guide. Wiley-Blackwell, UK.

EBENHARD T (1988). Introduced birds and mammals and their ecological effects. Swed. Wildlife Research, 13: 1-107.

EdELMAN AJ, Koprowski JL \& BerTELSEN S (2009). Potential for nest site competition between native and exotic tree squirrels. Journal of Mammalogy, 90:167-174.

Essl F, Klingenstein F, Nehring S, Otto C, RABITSCH W \& STÖHR O (2008). Schwarze Listen invasiver Arten - ein Instrument zur Risikobewertung für die Naturschutz-Praxis. Natur Landschaft, 83: 418-424. 
FALK JH (1976). Energetics of suburban lawn ecosystems. Ecology, 57: 141-150.

FEARE CJ (1984). The starling. Oxford University Press, New York.

Feinsinger P, Spers EE \& PoOle RW (1981). A simple measure of niche breadth. Ecology, 62: 27-32.

GotelLi NJ (2000). Null model analysis of species co-occurrence patterns. Ecology, 81: 2606-2621.

GOTELLI NJ \& ENTSMINGER GL.(2001). EcoSim: Null models software for ecology. Version 7.0. Acquired Intelligence Inc. \& Kesey-Bear. http:// homepages.together.net/ gentsmin/ecosim.htm.

HeLle P (1985). Effects of forest fragmentation on bird densities in northern boreal forests. Ornis Fennica, 62: 35-41.

Hinsley SA, Bellamy PE, Newton I \& SPARKS TH (1995). Habitat and landscape factors influencing the presence of individual breeding bird species in woodland fragments. Journal of Avian Biology, 26: 94-104.

KeRPEZ, TA \& SMITH NS (1990). Competition between European starlings and native woodpeckers for nest cavities in Saguaros. Auk, 107: 367-375.

Kestenholz M, HeER L \& Keller V (2005). Nonindigenous bird species established in Europe - a review. Ornithologische Beob.102: 153-180.

KoENIG WD (2003). European Starlings and their effect on native cavity-nesting birds. Conserv. Biol. 17: 1134-1140.

Kotaka, N \& Matsuoka, S (2002). Secondary users of great spotted woodpecker (Dendrocopos major) nest cavities in urban and suburban forests in Sapporo City, northern Japan. Ornithol. Sci. 1: 117-122.

KREBS CJ (1989). Ecological methodology. Harper Collins Publishers, New York.

JUNIPER T \& PARR M (1998). Parrots: a guide to the Parrot of the World. Pica press.

LÖVEI GL (1997). Global change through invasion. Nature, 388: 627-628.

MARTIN K \& EADIE JM (1999). Nest webs: A community-wide approach to the management and conservation of cavity-nesting forest birds. Forest Ecology and Management, 115: 243-257.

Martin K, AitKen KEH \& WiebE KL (2004). Nest sites and nest webs for cavity-nesting communities In Interior British Columbia, Canada: nest characteristics and niche partitioning. The Condor, 106: 5-19.

MARTIN TE \& LI P (1992). Life history traits of openvs. cavity-nesting birds. Ecology, 73: 579-592.

MATTHYSEN E, LENS L, VAN DONGEN S, VeRHEYen GR, WAUTERS LA, ADRIAENSEN F \& DHONDT AA (1995). Diverse effects of forest fragmentation on a number of animal species. Belgian Journal of Zoology, 125: 175-183.

MCKINNEY ML (2002). Urbanization, biodiversity, and conservation. BioScience, 52: 883-890.

MenNeChez G \& Clergeau P (2006) Effect of urbanisation on habitat generalists: starlings not so flexible? Acta Oecologica, 30: 182-191.

Mikusinski G, GROMADZKi M \& ChYLARECKI P (2001). Woodpeckers as Indicators of Forest Bird Diversity. Conservation Biology, 15: 208-217.

Mori E, Di Febbraro M, Foresta M, Melis P, ROMANAZZI E, NotARI A \& BOGgIANo F (2013). Assessment of the current distribution of freeliving parrots and parakeets (Aves: Psittaciformes) in Italy: a synthesis of published data and new records. Italian Journal of Zoology, 80: 158-167. http://dx.doi.org/10.1080/11250003.2012.738713

Newson SE, Johnston A, Parrott D \& LeECh DI (2011). Evaluating the population-level impact of an invasive species, Ring-necked Parakeet Psittacula krameri, on native avifauna. Ibis, 153: 509-516.

NILSSON, SG (1984). The evolution of nestsite selection among hole-nesting birds: the importance of nest predation and competition. Ornis Scandinavica, 15: 167-175.

OPDAM P, RiJSDIJK G \& Hustings F (1985). - Bird communities in small woods in an agricultural landscape: effects of area and isolation. Biological Conservation, 34: 333-352.

Pell, AS \& Tidemann, R (1997). The impact of two exotic hollow-nesting birds on two native parrots in savannah and woodland in eastern Australia. Biological Conservation, 79: 145-153.

PRANTY B (2002). The use of Christmas Bird Count data to monitor populations of exotic birds. American Birds, 56: 24-28.

REBELE F (1994). Urban ecology and special features of urban ecosystems. Global Ecology and Biogeographic letters, 4: 173-187.

ROBINSON RA, SIRIWARDENA GM \& CRICK HQP (2005) Status and population trends of Starling 
Sturnus vulgaris in Great Britain: Bird Study 52: 252-260.

SMITH, KW (2006). The implications of nest site competition from starlings Sturnus vulgaris and the effect of spring temperatures on the timing and breeding performance of great spotted woodpeckers Dendrocopus major in southern England. Annales Zoologici Fennici, 43: 177-185.

SNOW DW \& PERRINS CM (1998). The Birds of the Western Palearctic. Concise edition. Vol. I, Non Passerines. Oxford University Press, Oxford.

SPSS Inc. (2003) SPSS for Windows - Release 13.0 (1 Sep 2004), Leadtools (c), Lead Technologies Inc.

SPANÒ S \& TRUfFi G (1986). Il parrocchetto dal collare, Psittacula krameri, allo stato libero in Europa, con particolare riferimento alle presenze in Italia e primi dati sul pappagallo monaco, Myiopsitta monachus. Rivista italiana di Ornitologia, 56: 231-239.

StONE L \& ROBERTS A (1990). The checkerboard score and species distributions. Oecologia, 85: 74-79.

STRUBBe D \& MATTHYSEN E (2007). Invasive ringnecked parakeets Psittacula krameri in Belgium: habitat selection and impact on native birds. Ecography, 30: 578-588.
STRUBBE D \& MATTHYSEN E (2009a). Establishment success of invasive ring-necked and monk parakeets in Europe. Journal of Biogeography, 36: 2264-2278.

StRUBBE D. \& MATTHYSEN E. (2009b). Experimental evidence for nest-site competition between invasive Ring-necked Parakeets (Psittacula krameri) and native Nuthatches (Sitta europaea). Biological Conservation, 142: 1588-1594.

Strubbe D, Matthysen E \& Graham CH (2010). Assessing the potential impact of invasive ringnecked parakeets Psittacula krameri on native nuthatches Sitta europaea in Belgium. Journal of Applied Ecology, 47: 549-557.

SuMmer-SMITH JD (2003). The decline of the House Sparrow: a review. British Birds, 96: 439-446.

ZANGARI L, FERRAGUTI M, LUISELLI L, BATTISTI C \& BolognA MA (2013). Comparing patterns in abundance and diversity of hole-nesting birds in Mediterranean habitats. Revue d'Écologie (Terre Vie), 68: 275-282.

Received: June 16th, 2013

Accepted: May 16th, 2014

Branch editor: Isa Schön 